\title{
7 \\ MAKING BORDERS, CLOSING
FRONTIERS AND IDENTIFYING
SMUGGLING
}

Comparative histories

\author{
Paul Nugent
}

\begin{abstract}
Although there as many histories of border-making as there are lines on a map, most either involve some progression from a frontier to a border, or are the result of the splintering of an existing state/empire in which case internal borders are typically externalized. The frontier exists in the imagination of state actors, representing an area outside their conception of effective control. Their spatial reading, though, is not always shared by populations whose conception of the landscape of power may differ significantly. The border is more of an empirical reality and represents the point at which the writ of one authority definitively ends and another conceivably begins. The delimitation of a border by map and/or treaty may not result in immediate demarcation of a physical boundary, thereby contributing to a measure of uncertainty. When it comes to maritime borders, it stands to reason that proper demarcation is well-nigh possible. A popular misconception is that there is a sequence according to which states are formed and set out to define their borders, whereas these are generally simultaneous processes. As Peter Sahlins $(1988,1989)$ has demonstrated in relation to the protracted process of border-making between France and Spain in the Pyrenees, the border was initially actualized through the territorialisation of local identities. The territorialisation of the state itself, which involved the transplanting of institutions such as Customs officials to the margins, came much later - and the demarcation of the boundary line later still. This pattern holds for colonial states as well, as I have recently argued in the case of the Senegambia and the trans-Volta in the nineteenth century (Nugent 2019).

Ultimately, it is those who represent the sovereign authority who stipulate what may legally cross the border and under what conditions - and hence who also define what constitutes smuggling. Clearly, none of this resides inherently in the nature of the goods that are transacted: at certain times and places, the trade in narcotic substances (notably opium) has been considered legitimate, while seemingly innocuous goods like textiles and groundnuts have been identified as contraband. The act of labelling with a view to sanctioning is closely bound up with the aspirations of those who purport to rule, but what this means in practice depends on an underlying capacity to make a preferred version of order stick. If policing is intended to stamp out smuggling, the very act of cementing a border ironically renders contrabanding more attractive.
\end{abstract}




\section{Paul Nugent}

Borders have historically magnified differences, both because of the differential pace of infrastructural development and because of different regulatory regimes pertaining to taxation and consumption. Moreover, the riskier it becomes to move people and goods across the line, the greater the associated rents and the rewards that come with success. It is only at highly militarized land borders that flows are reduced to a trickle.

Inevitably, this is all bound up with contests over the moral as much as the physical terrain. Whether smuggling is driven by need or motivated by greed is fundamental to establishing the limits of acceptable behaviour amongst border populations - which has an important bearing on the ease with which enforcement is carried out. A prior question is whether the laws themselves are underpinned by any conception of the greater good. In this regard, it is worth recalling Adam Smith's sympathetic depiction of the smuggler as

a person who, though no doubt highly blamable for violating the laws of his country $\ldots$ and would have been in every respect an excellent citizen had not the laws of his country made that a crime which nature never meant to be so. (quoted in Evensky 2011, p. 260)

In border regions, it is not uncommon for populations to distinguish between smuggling that is considered harmless and that which is considered anti-social (Scheele 2012, pp. 95-124). This relates not just to the scale of the operation, but to the nature of the goods. Where the border is not considered legitimate in the first place, local actors may present smuggling almost as an act of social conscience. In cases where related populations straddle the line, as is true of the Awlad 'Ali of the Liberian/Egyptian borderlands, smuggling may even be integral to the reproduction of larger kinship networks (Hüsken 2019). Conversely, where the border is a consequence of a successful secessionist pitch, populations may be more inclined to co-operate in efforts to protect local agriculture and industry from goods entering from the other side. These shifts and nuances are what makes smuggling such a fascinating topic for historical enquiry and comparative reflection. In this chapter, I will seek to amplify these broad observations with reference to a range of different contexts in West Africa, South-East Asia, Western Europe and North America. These cases demonstrate that the logics of border-making have shaped patterns of smuggling, while the latter has been constitutive of social relations and political order.

\section{Border logics}

Frontiers are inherently ambiguous spaces: while underlying 'lawlessness' is associated with unpredictability and risk, frontiers also represent arenas of possibility for a multiplicity of actors. Indeed, states themselves may derive some benefit from loose arrangements - as with the slaving frontier exploited by the Dahomean kingdom in West Africa. The starting point is, therefore, to understand why states have found fixed borders desirable in the first place. In the European instance, prior to the emergence of properly defined borders, there were often overlapping and/or competing claims made by religious authorities, local nobles and of course rival statesin-the making (Sahlins 1989). Delimiting the border was about laying exclusive claims to populations and territory, while demarcation was an exercise in removing lingering ambiguities. In nineteenth-century Europe, this was associated with more effective technologies of mapping and better communications between the capital and the peripheries. Much of this technological know-how was transferred in short order to empire-building projects in Asia and Africa (Tagliacozzo 2005, pp. 28-47, 76-99). 
More specifically, there are a number of underlying patterns in boundary-making that are worth briefly mentioning here:

a. Firstly, states have often acted according to a defensive logic. In mountainous regions, claiming the heights of the land was typically justified on the grounds of establishing better surveillance and/or defensible positions. Creating a string of fortifications, or walled towns, as well as settling loyal populations in border regions, afforded a means for states to restrict the mobility of populations. Across Eurasia, the major threat historically came from men on horseback - as Chinese and Russian empire-builders learned to their cost along the expanse of the great Steppe (Barfield 1989; Khodorkovsky 2002). Colonial regimes that were struggling to assert their authority tended to place great store by securing their borders in the belief that dissidents were likely to take advantage of open frontiers. Although they were often in active competition with one another, colonial authorities had an incentive to co-operate in controlling the movements of potential rebels, as well as restricting the flow of firearms and ammunition. During the Cold War, highly militarized borders were intended to prevent almost any form of interaction across the line. This was reflected in the heavily mined border between Finland and the Soviet Union following the cession of Keralia and the excision of Finnish populations at the end of the Second World War (Paasi 1999). The land border between North and South Korea is an ongoing case where very little gets through (Kim 2014).

b. Secondly, borders have been drawn with the control of resources very much in mind. In densely settled regions, such as in western Europe and much of Asia, there was an incentive to lay claim to populations who were the ultimate source of revenue - whether directly in the shape of taxes or through labour service and levies on the products of the land. Cadastral mapping was an essential aid to improved systems of tax collection in Europe (Scott 1998, pp. 44-52), and the same technologies became fundamental to the demarcation of international borders. More counter-intuitive is the proliferation of mapping 'from below' which underlines the ways in which border populations became active participants in the creation of borders - a theme that emerges strongly in the cases of Alsace and Lorraine and Ghana/Togo (Dunlop 2015, Nugent 2002). Equally, states have had an interest in laying exclusive claims to natural resources - that is, wildlife, forests, fishing grounds, coal and deposits like copper and gold. The conversion of the resource frontier into something enclosed by state borders is exemplified by the manner in which the large swathes of open frontier that were exploited by fur trading companies were folded into imperial Canada.

c. Thirdly, asserting control over trade routes has been fundamental to the logic of bordermaking. Controlling coastlines with accessible ports, as well as the flanks of navigable waterways, has been a key strategic consideration. In Europe, the main river systems notably the Rhine and the Danube - have been fundamental to commercial flows, but also were the point at which state borders came together. Across much of Africa, ecologicallybased trade - for example between the coast, the Sahel and the Sahara in West Africa - was of considerable importance in the history of state formation. The taxation of goods in transit - such as copper, gold, salt and slaves - provided the material foundations upon which state builders consolidated their position. Although this did not necessarily require well-defined borders, rulers were careful to control chokepoints such as river crossings. Colonial regimes had a particular penchant for deploying rivers as borders for many of the same reasons - often choosing to locate the capital on the river. The twin capitals of Brazzaville and Leopoldville (Kinshasa) that face each other across the Congo river arose 
out of commercial and logistical considerations on the part of the French and the Belgians respectively (Gondola 2016, pp. 32-35). Inevitably, there was substantial traffic across the river during the colonial period, and this remains one of the most active theatres of smuggling to this day.

The most telling difference is not between colonial and non-colonial cases, but between the variable capacities of polities in general - ranging from states to more decentralized entities - to shape a clear agenda. Historically, weak states have tended to rely on intermediaries such as tax farmers and regional lords to manage their domains - building on bonds of allegiance rather than on territorial exactitude. In colonial contexts, the exploitation of resources was often left to private concessionary companies that exercised some of the vestiges of sovereignty on behalf of the metropolitan government. This was true of much of Central and Southern Africa and of South-East Asia (notably, Borneo). Where states had a greater capacity to intervene, they were more likely to post their own officials to designated border regions. But much depended on the willingness of local intermediaries to supply information and to co-operate in day-to-day enforcement of the regulations. Un-demarcated borders were perceived as a gift to local populations who were the masters of their own terrain and adept at exploiting lingering uncertainties. But they also increased the potential points of friction between neighbouring polities. In the case of the Cerdanya, Sahlins (1989, pp. 233-234) observes that it was the frequency of disagreements about where the border ran - typically when Customs officials were in hot pursuit of smugglers that informed the decision to delineate this section of the Spanish-French border. In colonial Africa, where aspiring colonial powers rubbed up against each other, bouts of feverish competition were generally followed by efforts to settle rival claims by treaty. Around Lake Kivu, Gillian Mathys 2014, pp. 127-128) reveals how the decision by the Belgians and the Germans to set up border posts mirroring each other at Goma/Gisenyi and Bukavu/Cyangugu between 1900 and 1906 was an exercise in setting down markers in what remained a disputed zone. The actual demarcation of the boundary between the Congo and Rwanda followed some years later. Although physical demarcation by boundary commissions was often delayed by decades, colonial regimes used maps and local agreements to navigate a way around potential misunderstandings. However, even agreeing on where the border ran did not necessarily translate into active cooperation when it came to regulating border flows - except when security was a serious issue. Colonial regimes feared the loss of people (and cattle) and often discouraged crossings into neighbouring territory whilst seeking to poach population from the other side. Those regimes that felt less affected by smuggling went through the motions of practising surveillance, but devoted minimal resources to it. At times, as we will see, they even provided their tacit consent.

In what follows, I will turn to three different patterns in the relationship between bordermaking and smuggling with reference to specific case-studies: those where smuggling was a response to colonial revenue imperatives; others where the intention was to restrict the flow of commodities, substances and people deemed dangerous; and still other cases where the border suddenly emerged in a moment of political rupture.

\section{Colonial revenue logics in West Africa: the Trans-Volta and the Senegambia}

In West Africa, most states reproduced themselves through taxes on trade, whether in the interior or at the coastal ports. It was much less attractive to tax populations directly - although in some places like the Sokoto Caliphate this was practised. A particularly well-documented 
polity is Asante which regulated the Hausa caravan trade from the Sahel. Hausa traders were directed to the trading town of Salaga and were not permitted to continue their journey to the capital. The trade to Kumasi and the metropolitan provinces was reserved for state traders and favoured merchants. Asante customs officials also taxed the goods which passed along the Volta river towards the coast. Ivor Wilks (1975, pp. 58-49) has identified a branch of the central bureaucracy whose specific role was to police the 'great roads' from designated control posts and to deal with the incidence of smuggling.

In the later nineteenth century, as the Europeans sought to exert influence well beyond the coastal trading posts, they came into direct conflict with inland states like Asante. The escalating costs of conflict became a source of concern for metropolitan governments. The response of local officials to the revenue imperative fell into an established groove. That is, they initially sought to establish their own control over chokepoints along the interior trade routes, to rebuff the efforts of internal polities to impose their own taxes, and finally to channel the trade to their own ports. However, the attempt to operate within the logics of the frontier became increasingly difficult, and as European rivalries intensified there was more of an interest in establishing spheres of influence and eventually colonies with defined borders. The emergence of the Gold Coast conforms to this pattern. After the British invasion of Asante in 1874, the kingdom lost control of the Hausa routes which increasingly passed down the eastern side of the Volta River. While the British authorities were under pressure from merchants to ensure that the trade from the interior came to them rather than their European competitors, the fledgling administrations at the coast desperately needed to raise income - especially once the Gold Coast colony (minus Asante) was formally consecrated in 1874. The failed attempt to introduce a poll tax culminated in a colonial state that balanced precariously on Customs duties. No sooner had the British defined their eastern border than a vigorous smuggling trade grew up at its eastern margins. In an effort to deal with the problem, the British shifted the border eastwards to include the town of Aflao in 1879 (Marguerat 1993, pp. 23-27). The pattern was repeated as traders from across the sub-region (including Hausas, Minas and Sierra Leoneans), and even some European firms, established themselves just beyond Aflao where there had previously been only a cluster of small fishing villages sandwiched between the sea and the lagoon. Hence Lomé, the present-day capital of Togo, owes its existence to its sudden emergence as a highly cosmopolitan haven for smugglers seeking to evade Gold Coast Customs controls (Marguerat 1998, Spire 2007). The favourable conditions for the contraband trade endured for some years before the Germans arrived on this stretch of coastline in 1884 and staked their own claim to what became the colony of Togo. The emergence of a rival colonial power required the British to agree on a formal border separating the two colonies, which closed the frontier once and for all. The result was the straight line border that remains in place today, running due north from the coast at Aflao and then taking a sharp deviation to the west. This was in no sense a natural border and in many ways provided the perfect conditions for the pursuit of smuggling.

After some years, the Germans decided to relocate their capital to Lomé and set about constructing a modern city with a wharf to handle ships and three railways to carry cash crops from the interior. The Germans and the British had initially agreed to harmonize their Customs duties, but this was abandoned by the Togo authorities when they needed to augment their revenues to finance the infrastructural push. Higher import duties in Togo resulted in considerable smuggling of manufactured goods from the Gold Coast. The Volta River constituted the border for much of its length and provided an easy route for contraband goods travelling in both directions. After the First World War, when France and Britain divided the German colony in two, the southern border remained intact, but further north it was shifted eastwards. For much of its length, the boundary was delimited and later demarcated along the line of the 


\section{Paul Nugent}

Togoland hills, in the hope that it might constitute a more natural border. However, the routes through the forested mountains proved extremely difficult for the Gold Coast Customs Preventive Service (CPS) to patrol. Meanwhile, at the coast it was business as usual. British trading firms operated stores in Lomé that notionally catered to the local market. Many of the imported goods that they sold, however, were transported across the border into the Gold Coast, either by pirogues along the lagoons or the sea-route, or overland along countless trails. The most important single item in the contraband trade was Dutch gin. The British relied overwhelmingly on import duties, and the greatest single contributor to these was the duty on gin, followed by textiles and tobacco (Nugent 2019, p. 262). The French maintained head taxes and minimized the level of import duty. Although much of the contrabanding was carried out by small traders, some of the seizures effected by the CPS pointed to something altogether more organized (Nugent 2019, 262-268). Whereas the CPS devoted considerable energy to the campaign against smuggling in the 1920s, the French authorities devoted minimal resources to this aspect of border control.

In the Senegambia, the picture was somewhat different because the control of labour was closely intertwined with the flow of commodities. The British and the French initially established trading posts at Bathurst and Saint Louis with a view to tapping trade along the Gambia and Senegal rivers respectively. However, by the mid-nineteenth century, the production of groundnuts in proximity to the coastal ports had shifted the centre of economic gravity. In the 1880s, the French resolved to claim the entirety of the Senegambia, pegging the Portuguese backwards towards Bissau and encircling the British in the process. Given vocal opposition to relinquishing Bathurst, the question of defining a border between the Gambia and Senegal became a practical necessity. In the western sector, a major consideration for the British was slave raiding. By settling on a border in 1889, and securing French co-operation, the British hoped to establish the conditions that would enable the Jola to cultivate groundnuts in peace. The boundary was drawn according to a simple expedient - comprising a straight line from the coast, followed by one that tracked the contours of the Gambia river at 10 kilometres from either bank (Nugent 2019, pp. 120-122). Again, this was anything but a natural boundary, even if it shadowed a natural feature.

Just as British firms controlled much of the trade in Lomé, it was French firms that dominated the trade of the Gambia, which they conducted from wharf towns dotted along the river. Once slave raiding had been eliminated, the Gambian groundnut economy depended heavily on seasonal labour, or 'strange farmers,' drawn from French territory. Part of the attraction for these workers was to acquire access to British manufactured goods. In addition, Senegalese producers smuggled their own groundnuts into the Gambia in order to be able to purchase these same commodities from the wharf towns that were substantially closer. Moreover, the Gambia suffered from a chronic food deficit, especially at times when the migrant labourers were present in large numbers. Although the Gambia imported rice to cover the shortfall, much of it was smuggled in from French territory. All of this was convenient for the Gambian authorities because they were able to maximize their groundnut exports and also to increase the sale of British manufactures, both of which were taxed.

In significant ways, British and French priorities were aligned very differently. While the French endeavoured to maintain a tight Customs cordon, the British displayed little interest in regulating what crossed the border - other than firearms, the occasional marabout (or religious leader) and stolen cattle. However, the two sets of authorities did have a shared interest in formalizing the strange farmer system. The latter was fundamental to the economic viability and public finances of the Gambia, but migrants also earned money that enabled them to pay their head taxes in Senegal and Mali. The authorities co-operated to ensure that they were registered 
and did not criss-cross the border at will. However, this depended on the co-operation of the alkalos (village chiefs) in the Gambia who managed the system. While the alkalos received their cut, there was inevitably some temptation to let migrants enter beneath the radar of the two administrations. While the British favoured permanent settlement, they sought to stamp out the practice of short-term migrants bypassing the controls. Although they co-operated in managing migration, the Senegalese authorities suspected their Gambian counterparts of actively poaching population with a view to promoting permanent settlement. This became a hot issue during the First World War when many people crossed the border to escape conscription.

The trans-Volta and Senegambia cases throw up some interesting parallels and differences. In the Senegambia, the flows that were regulated were people as well as commodities, and the latter included a cash crop (groundnuts), food crops and imported consumer goods. In the trans-Volta, some cocoa was produced, but its production did not depend on labour from across the border, while the trade in foodstuffs was less important. The importance of everyday consumer goods, however, was as evident, even if alcohol featured less in the list of Gambian smuggled goods. In both cases, the leading commercial enterprises were complicit in the contraband trade. British firms in Lomé were well-aware that the imported commodities that they sold were likely to end up in the Gold Coast, although their standard defence was that they had no control once the goods entered the hands of their customers. In the Gambia, French firms sold the British manufactured goods that made their way across the Senegalese border, while they purchased contraband groundnuts that travelled in the opposite direction. In each case, the huff and puff surrounding the campaign against smuggling on one side of the border contrasted with the almost complete lack of interest on the other. Finally, populations who found themselves located on either side of the line adapted creatively to these realities. Borderlanders knew the inland waterways intimately and they were able to make use of the many paths and tracks that criss-crossed the landscape. The difference was that whereas Senegambian smugglers made extensive use of horse and donkey carts, their trans-Volta counterparts were more dependent upon the headloading of smuggled goods. In no sense can smuggling be considered something that existed in ignorance of the border - although such a defence was frequently invoked by those who were caught red-handed. Much like in Cerdanya, populations were well-aware of where the borders ran, even if these were not always clearly demarcated on the ground. A.I. Asiwaju (1976, p. 201) has referred to the emergence of linked markets all along the colonial border between Benin and Nigeria, underlining the ways in which populations appropriated the border. Much the same was true of the trans-Volta and the Senegambia where rotating markets became a defining feature of the borderlands.

\section{Dangerous goods, noxious substances}

Aside from taxing goods, the other main source of smuggling resulted from efforts to control the movement of commodities deemed dangerous to some conception of morality and/or social order. This was a particular consideration in an imperial context where hegemony often dangled by a very flimsy thread. The passage of Muslim religious tracts was monitored very closely across West Africa, especially texts that were thought to harbour seditious intent and possibly a coded call to jihad. Firearms loomed large for the obvious reason that they afforded the means to mount resistance. In the Arabian Sea (Mathew 2016, pp. 82-112) and in the watery expanse of South East Asia (Tagliacozzo 2005, pp. 260-282), there was a very substantial traffic in firearms that European consuls and colonial regimes struggled to contain. The lack of clear maritime borders - despite the agreement of the British and the Dutch to draw a line through the Straits of Melaka in 1871 (Tagliacozzo 2005, p. 29) - together with the sheer scale 


\section{Paul Nugent}

of the trading zone, made this an almost impossible task. The Dutch faced a particular problem subduing the rulers of Aceh in the early 1870s and endeavoured to impose a blockade. In the West African colonies, the French opposed permitting African access to firearms whereas the British were more inclined to accept a case for their use in hunting and to tax their purchase accordingly (Sané 2008). In the Senegambia, there was a vigorous illicit trade in arms and ammunition between the Gambia, the Casamance region of Senegal and the Portuguese colony of Guinea Bissau which was closely bound up with moments of armed resistance. The same pattern was evident on the border between Benin and south-western Nigeria, where arms and ammunition smuggled into the former was deployed in opposition to French rule (Asiwaju 1976, p. 200).

In the case of narcotics, the disastrous social consequences of opium addiction were well known from the Chinese experience. In the East Indies, the British and Dutch authorities were keen to prevent a spillover into their own domains. However, they did not seek to ban the drug, but rather to regulate its supply and consumption. Hence, the rights to sell opium were generally farmed to Chinese merchants in return for a commission. Tagliacozzo (2005, p. 201) points out that populations were subject to distinct rules relating to consumption of narcotics, while the cost of the opium 'farms' differed between the British and Dutch territories. Not surprisingly, therefore, smugglers moved opium from where it was relatively cheap to where it was more expensive. In addition, smugglers imported their own supplies of opium to the region, with Singapore serving as a conduit into the Dutch possessions. The numerous islands and broken coastlines of the sub-region provided the perfect environment in which opium smugglers could transport and conceal consignments of a relatively low bulk, high value commodity.

A strikingly similar story unfolded in the far western borderlands between the United States (US) and Canada. Here, a straight-line border had been drawn along the forty-ninth parallel in 1846, but it was a line on a map and was not really enforced to start with. The Customs presence was minimal, especially along the coast where some areas remained in dispute (Moore 2014, pp. 15-16). Stephen T. Moore indicates that British Columbia had always been more closely connected to neighbouring American states than the rest of Canada, while populations and consumer items like cotton goods and tobacco had moved relatively freely across the line. The borderlanders themselves regarded such smuggling as morally acceptable and, as is so often the case, took a certain pride in running rings around the revenue men. However, it was the passage of items deemed subversive to the social order in the US that led to a more sustained attempt to police the border. Opium was banned in the US in 1914, but not in Canada, which meant that there was a lively trade from one to the other. Moreover, following the American decision to forbid Chinese immigration in 1882, an active trafficking route through British Columbia opened up (Moore 2014, p. 17). As in South-East Asia, much of the smuggling was conducted by water along a broken coastline that was very difficult for an under-resourced coastguard to patrol (Moore 2014, p. 19). The extensive land border made detection equally difficult, not least because of the terrain.

The other item that was of increasing interest to the US authorities was alcohol. Temperance ideas took root on either side of the border in the later nineteenth century, reflecting the manner in which missionaries and activists criss-crossed the line. Although British Columbia itself went dry during the First World War, this changed just as the Americans passed the Eighteenth Amendment that enshrined Prohibition in the US Constitution. Under the Canadian Constitution, the regulation of alcohol production and alcohol was a federal matter, and the government had no desire to co-operate in the banning of alcohol exports to the US which were a source of much-needed taxes. Much of the alcohol that was notionally destined 
for Central and South America was instead channelled to US ports. Running alcohol across the border became a major business which the Canadian Customs authorities did conspicuously little to address. Indeed, they even tolerated it as long as the perpetrators refrained from the drugs trade (Moore 2014, p. 61). The contraband business ultimately benefited brewers and distillers, the bootleggers and the public exchequer in Canada. It also enjoyed the sympathy of border populations, especially those living closest to the line. A comparable story can be told for the Mexican border (Martinez 1975, pp. 57-77). Canadian manufacturers were the most vocal critics for the reason that as alcohol went south, items such as tobacco and textiles were smuggled northwards. In the end, it was the repeal of the Eighteenth Amendment that brought the bootleggers' boom to an end.

\section{The irruption of the border}

When a border was newly established, governments generally felt impelled to make a statement by establishing control posts. The practical consequences, however, depended on how amicable the divorce settlement had actually been. One instructive example of the ways in which borders can create an environment conducive to smuggling follows the carving of the Free State out of Ireland in 1922. While 26 Catholic-majority counties joined the new state, a rump of six counties remained within the United Kingdom as Northern Ireland. The two governments immediately established Customs posts where none had existed before, despite the fact that there were many unresolved issues about where the border ought to run. Peter Leary (2016, pp. 41-45) observes that Catholics tended to be concentrated on marginal lands in the hills, while Protestants predominated in the more fertile low-lying areas. Catholics and Protestants had tended to frequent different market towns, but the net result of the border was that many discovered that these were located on the other side of the border. Although farm produce was initially exempt, it was necessary to pay duty on everyday items like soap, tea and cigarettes. Moreover, border shoppers were required to use approved crossings even if the goods were not dutiable, and this frequently involved an inconvenient detour. While the Customs regulations were not wildly divergent to start with, this changed as inter-governmental relations deteriorated. In Dublin, the mood was in favour of protectionism after 1932, while the British authorities introduced hefty duties on Irish goods as a form of retaliation. Following tit-for-tat exchanges, even agricultural products were covered by duty. The imposition of a $40 \%$ duty on Irish cattle entering Northern Ireland was particularly stiff (Leary 2016, pp. 130-131). While nationalist sentiment justified imposing higher duties, these potentially had a detrimental impact on border populations who depended on supplies from the other side. The inevitable consequence was that smuggling flourished, and while governments on the two sides might appeal to patriotic duty, this enjoyed little traction - for reasons that Adam Smith would certainly have understood. Poor Catholics found a way to fashion an income from smuggling, while Protestants grandees in the north were secretly implicated. Apart from cattle, whisky and cigarettes and clothing were widely smuggled. In 1938, the two governments attempted to call a halt and signed a treaty covering trade co-operation. However, the shortages of the war years, during which Ireland remained neutral, led to the systematic smuggling of everyday items like bread, sugar, flour and tea. By this point, there was no real doubt about where the border ran. On the contrary, it was fundamental to the dynamics of the contraband trade.

The redrawing of European borders after the Second World War and the rapid onset of the Cold War, followed by the eventual collapse of the Soviet Union, involved massive population displacements and acute consumer shortages that were reflected in smuggling. In post-colonial Africa, by contrast, the borders remained remarkably stable despite their supposed artificiality. 
There has been, though, a proliferation of armed insurgencies in which rebel movements move back and forth across borders to escape detection. Crucially, they also finance their operations, re-arm themselves and nourish their fighters, from the profits of smuggling - typically based on the trafficking in natural resources like timber, precious metals and cattle. However, where movements have been able to secure de facto control over territory, they have tended to mimic the revenue-collection practices of state entities. In a handful of instances, rebel movements have aspired towards creating their own breakaway states, in which cases smuggling has actually been the hand-maiden of border-making. This is true, for example, of the Sudan Peoples' Liberation Movement/Army (SPLM/A) which was always deeply implicated in cross-border trade across the sub-region (Walraet 2013, 179-180). Once formal separation has taken place, it is difficult for post-liberation governments to turn off the tap. In the case of South Sudan, the transition was particularly messy because the border with Sudan, which contains valuable oilfields, remained in dispute, while fighting between factions of former SPLM/A stood in the way of the creation of an effective central government. Hence the performance of border rituals and bureaucratic formalities along particular borders crossings (De Vries 2013, p. 154) has coexisted with systematic involvement of the protagonists in the contraband trade.

\section{Conclusion}

Drawing on a wide range of case-studies, this chapter has distilled some underlying patterns in the relationship between border-making and smuggling which can now be summarized. Firstly, the manner in which the border took shape has had a significant bearing on the trajectories of smuggling. In cases where frontiers solidified into borders, the desire to regulate the flow of people and goods was fundamental to the decisions to delimit and eventually to demarcate. This is apparent from the works of Sahlins on the Spanish-French border $(1988,1989)$ and Tagliacozzo (2005) on colonial South-East Asia. Holding the line generally went together with an official discourse on the evils of smuggling, although states and their minions often benefited from it. Across these cases, what is clear is that while the authorities fretted about unclear boundaries, border populations were well-aware of where the lines ran and profited accordingly.

Secondly, where the border was located wielded an important influence on the capacity of governments to exercise meaningful control. Maritime borders were largely un-demarcated, even if they were minutely detailed on maps, and this always created some leeway for interpretation. Mountainous borders were demarcated, but only up to a point. In unforgiving terrain, the dice were generally loaded in favour of the smugglers. Thirdly, the dynamic of any given border was closely bound up with the ways in which states pieced together their revenue streams. In colonial West Africa, the balance between import duties and direct taxes created a context in which goods were smuggled routinely while people crossed borders to evade direct taxation and conscription. Fourthly, the intent behind tightening borders was often related to the traffic in commodities that were deemed injurious to the public good - including firearms, alcohol and narcotics, even if each of these was also taxed in particular instances. Finally, where borders came into existence abruptly, the same dynamics manifested themselves, but often in a telescoped manner. Borders on paper needed to be translated to the landscape. Nationalists have also been tempted by the benefits of protectionism. Border populations have generally been sensitive to everyday inconvenience, but also to the opportunities that the existence of the border presents. As the Irish and US/Canadian cases illustrate, however, engagement in smuggling is not in and of itself an indicator of the illegitimacy of a given border. In Africa, engagement in contrabanding was paradoxically what enabled borders to be internalized 
(Nugent 2002). Borderlanders generally came to accept the downsides of partition because of the livelihoods that smuggling sustained. At the same time, contraband has underpinned kinship relations and regional religious networks, as indicated by Hüsken (2019), whilst forging new kinds of connections between commercial centres embedded within larger systems of connectivity as demonstrated by Nugent (2019) and Scheele (2012) for West Africa. In that sense, smuggling has had productive effects that are not fully captured by the association with deviance and evasion.

\section{References}

Asiwaju, A.I., 1976. Western Yorubaland under European rule 1889-1945. London: Longman.

Barfield, T.J., 1989. The perilous frontier: nomadic empires and China 221 BC to AD 1757. Oxford: Blackwell.

De Vries, L., 2013. Pulling the ropes: convenient indeterminacies and the negotiation of power at Kaya's border checkpoint. In C. Vaughan, M. Schomerus and L. de Vries eds. The borderlands of South Sudan. New York: Palgrave Macmillan, 143-172.

Dunlop, C.T., 2015. Cartophilia: maps and the search for identity in the French-German borderland. Berkeley, Los Angeles \& Oxford: University of California Press.

Evensky, J., 2011. Adam Smith's essentials: on trust, faith, and free markets. Journal of the History of Economic Thought 33(2), 249-267.

Gondola, C.D., 2016. Tropical cowboys: westerns, violence, and masculinity in Kinshasa. Bloomington: Indiana Press.

Hüsken, T., 2019. Tribal politics in the borderland of Egypt and Libya. New York: Palgrave Macmillan.

Khodarkovsky, M., 2002. Russia's steppe frontier: the making of a colonial empire, 1500-1800. Bloomington \& Indianapolis: Indiana University Press.

Kim, S.-Y., 2014. DMZ crossing: performing emotional citizenship along the Korean border. New York \& Chichester: University of Columbia Press.

Leary, P., 2016. Unapproved routes: histories of the Irish border, 1922-1972. Oxford: Oxford University Press.

Marguerat, Y., 1993. Dynamique urbaine, jeunesse et histoire au Togo: articles et documents (1984-1993). Lomé: Presses de l'UB.

Marguerat, Y., 1998. Les deux naissances de Lomé: une analyse critiques des sources. In N. Gayibor, Y. Marguerat and K. Nyassogbo eds. Le centenaire de Lomé, capital du Togo (1897-1997). Lomé: Presses de l'UB, 59-77.

Martinez, O.J., 1975. Border boom town: Ciudad Juarez since 1958. Austin \& London: University of Texas Press.

Mathew, J., 2016. Margins of the market: trafficking and capitalism across the Arabian Sea. Oakland: University of California Press.

Mathys, G., 2014. People on the move: frontiers, borders, mobility and history in the Lake Kivu region, 19th-20th Century. Thesis (PhD). University of Ghent, 2014.

Moore, Stephen T., 2014. Bootleggers and borders: the paradox of prohibition on a Canada-U.S. borderland. Lincoln: University of Nebraska Press.

Nugent, P., 2002. Smugglers, secessionists and loyal citizens on the Ghana-Togo frontier: the lie of the borderlands since 1914. Athens \& Oxford: Ohio University Press \& James Currey.

Nugent, P., 2019. Boundaries, communities and state-making in West Africa: the centrality of the margins. Cambridge: Cambridge University Press.

Paasi, A., 1999. Boundaries as social practice as discourse: the Finnish-Russian border. Regional Studies 33(7), 669-680.

Sahlins, P., 1988. The nation in the village: state-building and communal struggles in the Catalan borderland during the eighteenth and nineteenth centuries. Journal of Modern History 60(2), 234-263.

Sahlins, P., 1989. Boundaries: the making of France and Spain in the Pyrenees. Berkeley, Los Angeles \& Oxford: University of California Press.

Sané, S., 2008. Le côntrole des armes à feu en Afrique occidentale française 1834-1958. Paris \& Dakar: Karthala \& CREPOS.

Scheele, J., 2012. Smugglers and saints of the Sahara: regional connectivity in the twentieth century. Cambridge: Cambridge University Press. 


\section{Paul Nugent}

Scott, J.C., 1998. Seeing like a state: how certain schemes to improve the human condition have failed. New Haven \& London: Yale University Press.

Spire, A., 2007. Kodjoviakopé à Lomé: le temps et la constitution d'un terroir urbain. In P. GervaisLambony and G.K. Nyassogbo eds., Lomé: dynamiques d'une ville Africaine. Paris: Karthala, 189-210.

Tagliacozzo, E., 2005. Secret trades, porous borders: smuggling and states along a Southeast Asian frontier, 1865-1915. New Haven \& London: Yale University Press.

Walraet, A., 2013. State-making and emerging complexes of power and accumulation in the Southern Sudan-Kenyan border area: the rise of a thriving cross-border business network. In C. Vaughan, M. Schomerus and L. de Vries eds., The borderlands of South Sudan. New York: Palgrave Macmillan, 173-192.

Wilks, I., 1975. Asante in the nineteenth century: the structure and evolution of a political order. Cambridge: Cambridge University Press. 